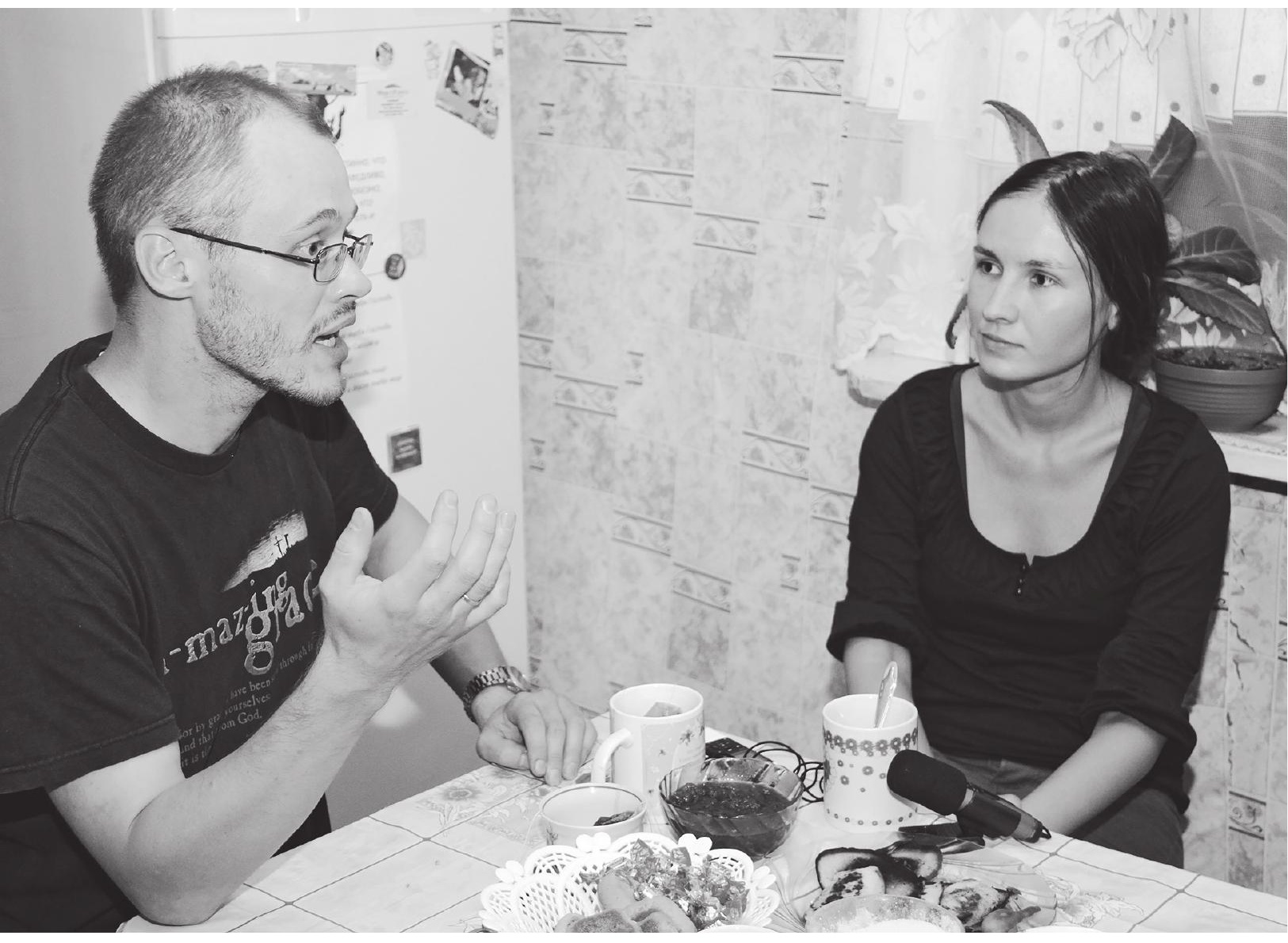




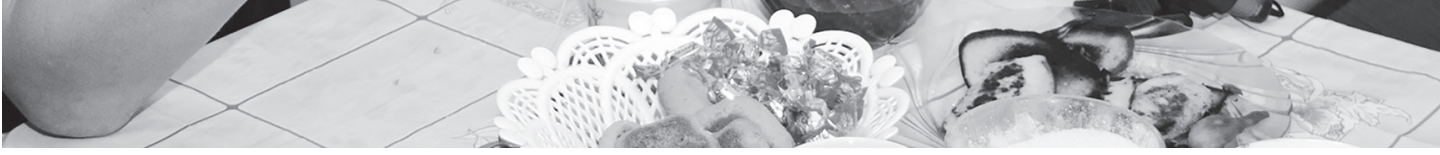

ERMi aastaraamat 61 (2018), Ik 134-153

DOI: $10.33302 /$ ermar-2018-006

\section{Etnoloogilised välitööd religioosses kontekstis Komimaa kristlaste näitel ${ }^{1}$}

Piret Koosa

\section{Sissejuhatus}

Refleksiivsust ja objektiivsust puudutava problemaatika silmas pidamisel on oluline osa etnoloogi tööprotsessis, erilist tähelepanu nõudvaks on neid küsimusi peetud religiooni puudutavates uurimustes (vt nt Wanner 2011: 223; Lambek 2012). Olles kümne aasta vältel uurinud Komimaa usuelu arenguid ja teinud välitöid nii õigeusklike kui evangeelsete kristlaste seas, on nende aspektidega seotud küsimused kerkinud sageli esile nii minu enda kui ka uuritavate poolt püstitatuna. Selles artiklis arutlen oma positsiooni üle mitteuskliku etnoloogina evangeelsete kristlaste seas välitöid tehes. Käsitlen enda ja uuritavate suhte erinevaid tahke ja arutlen tehtud metodoloogiliste valikute üle. Analüüsides oma kogemusi „väljal“, loodan panustada diskussiooni, mis puudutab

[...] isiklike uskumuste ja suhtumiste rolli antropoloogilises teoorias ja praktikas ning nende mõju mitte ainult teadusliku teadmise loomisele ja publitseerimisele, aga ka isiklike suhete sõlmimisele ja sotsiaalsele suhtlusele etnograafilise praktika käigus (Blanes 2006: 224).

Kalduvust pidada mitteuskumist „objektiivseks“ vaateks on nimetatud süstemaatiliseks eelarvamuseks, mis iseloomustab enamikku usku käsitlevaid akadeemilisi uurimusi (Hufford 1995: 61). See on ajendanud kriitiliselt analüüsima antropoloogi enda maailmavaate ja veendumuste mõju religiooni uurimisele. Oma ja võõra dihhotoomiat käsitledes on keskne küsimus üldjoontes olnud see, „mil määral, kui

[1] Varasem versioon artiklist on ilmunud inglise keeles: Koosa, Piret 2017. "If you're really interested in scientific research, you should study the Bible!" Ethnographical fieldwork among evangelical Christians. - Body, Personhood and Privacy: Perspectives on the Cultural Other and Human Experience. Approaches to Culture Theory 7. Tartu: University of Tartu Press, 53-71.

Pastor Andrei ja artikli autor vestlemas. 
üldse, [...] inimeste kombed ja uskumuste motiivid ja tähendused on ligipääsetavad uurijale, kes ei pruugi neid uskumusi tingimata jagada ega osale tingimata neis praktikates" (McCutcheon 1999: 2). Ühelt poolt näib oma ja võõra eristamine olevat ilmne ja kasulik: on selge, et mingi grupi liikmetel on privilegeeritud ligipääs oma rühma teadmistele, ressurssidele, autoriteedile. Teisalt on religiooni uurimises sel elementaarsel empiirilisel erisusel sageli arvatud olevat sügavamad epistemoloogilised eeldused ja mõjud (Gardiner, Engler 2012: 239). Oma ja võõra vaatenurga vastandamist religiooni uurimisel on peetud ka pseudoprobleemiks, osutades, et seda erisust kiputakse sotsiaalteadustes müstifitseerima (Jensen 2011: 30-31, 46). Näiteks on Jeppe Sinding Jensen (samas: 30, 32, 46) väitnud, et niisugune eristamine on akadeemilises uurimistöös kasutu, kuna sel puudub metodoloogiline või teoreetiline väärtus religioonide uurimisel. Samamoodi on Mark Q. Gardiner ja Steven Engler vaielnud vastu arvamusele, et usklike keelekasutuses või kogemustes on midagi sellist, mis oleks põhimõtteliselt ületamatu takistus nende keele või praktikate mõistmisel (Gardiner, Engler 2012: 241).

Kui väga antropoloogid ja etnoloogid ka ei tahaks näha end objektiivsete vaatlejatena, ei saa me eirata tõika, et meie distsipliin

[...] paigutub laiale diskursiivsele väljale, mille on moodustanud sekularism ja religioon ning see [antropoloogia] on alati olnud huvitatud osapool nendevahelises debatis, laveerides selgituse ja tõlgenduse, demüstifikatsiooni ja tunnustamise, transtsendentaalse teadmise ja immanentse kogemuse vahel (Lambek 2012).

Et mitteusklikkust ei saa pidada erapooletuks vaateks „ei kusagilt“ (Hufford 1995: 61), on oluline, et kogukonnale väljastpoolt lähenev uurija oleks kriitiline omaenda eelduste ja arvamuste suhtes - seda enam, et neid peavad oluliseks ka meie partnerid „väljal“. Propageerimata lihtsalt uuritavate enesekuvandit (vt Jensen 2011: 33) arvan, et etnoloogilist uurimistööd tehes on minu kohus püüda tegeleda nii oma välitööpartnerite tõstatatud küsimustega kui ka omaenda oma ja võõra jaotust puudutavate mõtete ja kogemustega.

„Väljal“" viibides olen olnud n-ö õpilase rollis ning tundnud end eriti välitööde algusperioodil, aga ka hiljem kohati üpris ebakindlalt. Ebakindlus ja kõhklused teatud olukordades on suuresti olnud seotud sellega, mida mõned mu mitte-evangeelsed informandid on endast kõneledes nimetanud „religioosseks kirjaoskamatuseks “. ${ }^{2}$ Et mul puudus varasem kirikuskäimise ja religioosselt pühendunud inimestega suhtlemise kogemus, olen teatud olukordades ebalenud, millist käitumist minult eeldatakse, millised on kohased küsimused või reageerimisviisid. Seevastu artiklite kirjutamise ajal on mul kogutud välitöömaterjalide tõlgendamisel abiks nii teiste autorite uurimused kui teoreetiline kirjandus, millele viidata. Oluline erinevus välitöösituatsioonis viibimisega on ka see, et on aega kogutud materjali üle mõtelda ja sobilike tõlgendusteni jõuda, samas kui „,väljal“ viibides tuleb sageli kohe reageerida ning seega ei saa olla kindel parima võimaliku käitumis- ja vastamisviisi valikus.

[2] Seda väljendit kasutades peavad inimesed silmas, et nad ei tea täpselt, kuidas kirikus õigesti käituda - õigeusu kirikutes kehtivad enamasti üsna ranged rõivastumis- ja käitumisreeglid. 
Üks oluline aspekt etnoloogi ja uuritava(te) suhtes on võimalik ja õigupoolest tõenäoline erinevus kahe osapoole tõlgendustes. On täiesti loomulik ja ootuspärane, et mistahes kaks osapoolt võivad sama juhtumit või olukorda mõista erinevalt, kuid etnoloogil on võimupositsioon uuritava kuvandi loomisel laiema avalikkuse silmis. Ka võib suuresti erineda see, mis on oluline ühelt poolt usklike ja teiselt poolt uurija arvates. Omajagu väljakutseid pakub inimeste kogemustes ja eneserepresentatsioonides kajastuva mitmekesisuse, sageli ka vastuolulisuse edasiandmine akadeemilise artikli vormis, mis eeldab teatud selgust ja konkreetsust uurimistulemuste esitamisel. Veelgi keerulisemaks ja käsitlemisel suurt tundlikkust nõudvaks teeb taolise materjali asjaolu, et kogukond ise või selle üksikud liikmed ei pruugi uurija tajutud konflikte ja vastuolusid sellistena näha. Uuritavate võimalikult ausal kujutamisel on seega oluline püüda nende endi seisukohti selgelt esile tuua, et need ei jääks võ̃ra perspektiivi varju.

Esmakordselt oma „väljale“ sisenedes oli mul valitud uurimisteema tõttu mitmeid kõhklusi. Esiteks pidasin võimalikuks usklike ükskõiksust või isegi vaenulikkust "teadusliku uurimistöö" suhtes. Sel juhul oleks tõenäoline, et inimesed keelduvad suhtlemast minu esitatud eesmärkidel - kui suudan neid üldse arusaadavalt selgitada. Asjaolu, et kaldusin nägema usukogemusi üpris isiklikena, ${ }^{3}$ suurendas minu kõhklusi selles osas, kuivõrd on inimesed valmis neid võõraga jagama. Kui ühelt poolt tegi mulle muret, kuidas leida ligipääsu evangeelsetele kristlastele, siis teisalt olin teadlik ka võimalusest, et satun jõulise ja isegi agressiivse misjoneerimise objektiks. Sellega seoses kartsin, et minuga ollakse valmis suhtlema vaid niivõrd, kuivõrd näitan üles valmisolekut usku pöörduda - seda mul aga polnud ja pidasin ka ebaausaks jätta vastupidist muljet.

Järgnevalt tutvustan esmalt põgusalt oma „välja“ ning arutlen oma mõtete, kogemuste ja tunnete üle mitteusklikuna usklikke uurides. Seejärel käsitlen usklike reaktsioone enda suhtes ja analüüsin, kuidas minu positsioneerumine uurijana on meie suhtlemist mõjutanud. Mõtisklen ka erinevate motiivide üle, mis on ajendanud inimesi selles suhtluses osalema ning käsitlen oma eesmärkide selgitamisega kaasnenud problemaatikat.

\section{"Väli”}

Aastatel 2008-2015 Komi Vabariigi Kulömdini (Ust-Kulomi) rajoonis toimunud välitööde ${ }^{4}$ käigus olen keskendunud väikesele evangeelsete ${ }^{5}$ kristlaste kogukonnale Doni külas (vt Koosa 2017). Esimest korda käisin Komimaal välitöödel 2006. aastal - toona olid uurimisfookuses üldisemad muutused ja suundumused nõukogu-

[3] Olen teadlik, et niisugust seisukohta võib pidada protestantismist mõjutatud vaateks.

[4] Välitööd toimusid koos Art Leetega. Minavormi asemel mitmuse kasutamine käesolevas tekstis lähtub asjaolust, et enamik intervjuudest ja vestlustest on salvestatud meie mõlema juuresolekul.

[5] „Evangeelne" osutab siin angloameerika protestantlike äratusliikumiste traditsioonile, tähistades kristlasi, kes rõhutavad isikliku uskupöördumise olulisust, evangeliseerimise tähtsust ja piibli fundamentaalset autoriteeti usuküsimustes. 
de aja järgses usuelus Komi külades (vt Koosa 2010; Koosa, Leete 2011). Vesteldes kohalike inimestega, kelle identiteedis on suurem või väiksem roll õigeusul, ilmnes peagi, et rajoonis tegutseb aktiivselt ka evangeelsete kristlaste kogukond. Tähelepanek, et paljud külaelanikud olid sellest asjaolust ärritatud, ajendas pöörama tähelepanu kõnealusele grupile ja grupi liikmete suhetele laiema kogukonnaga. Kontakteerusime grupi pastoriga ning selgitasime talle oma huvi ja tegevuse eesmärke. Seejärel tutvustas pastor Andrei meile ameeriklasest misjonäri Williamit, kelle tegevuse tulemusena oli grupp tekkinud, ning hiljem ka ülejäänud kogudusele. ${ }^{6}$ Ka hiljem on pastor Andrei meid kõnepuldist korduvalt tutvustanud kohalikust usuelust huvitatud teadlastena ning julgustanud inimesi meiega oma kogemusi jagama. Et sellega on pastor oma kogudusele justkui kinnitanud, et meiega suhelda on „,turvaline", on taoline tutvustamine meile meie töös kindlasti abiks olnud, ehkki mõistagi ei ole see taganud „,automaatset ligipääsu“ koguduse liikmetele.

Vaatamata sellele, et pastor Andrei on viidanud meile kui teadlastele, ja hoolimata meie endi selgitustest, on meie enesemääratlus etnoloogidena usklike jaoks siiski sageli segaseks jäänud ning vähemasti mõned grupi liikmetest peavad meid endale sarnaselt usklikeks. Näen selle asjaolu taga peamiselt kaht põhjust. Kogukonnal on aktiivsed suhted välismaiste koguduste ja usklikega ning kohalikud evangeelsed kristlased on harjunud sellega, et aeg-ajalt saabuvad neile külla usuõed ja vennad Ameerikast, Saksamaalt, aga ka Eestist. Seega ongi komi usklike jaoks olnud loogiline arvata, et oleme samalaadsed külalised, ja vaatamata osutustele, et oleme ülikooliga seotud uurijad, on inimesed ikka küsinud meie kodukiriku ja muu taolise kohta. Teisalt, tingituna kohaliku sotsiokultuurilise konteksti eripärast suhtutakse evangeelsetesse kristlastesse Komi külades tihti umbusu ja eelarvamustega, mistõttu meie heatahtlik huvi ja valmisolek kuulata on samuti hägustanud meie võorra-staatust. Ka salvestusseadmete kaasamine, et vestlust jäädvustada, ei osuta tingimata kõrvalseisja rollile, sest inimesed on harjunud evangeelsete väljaannetega, milles kirjeldatakse usklike pöördumislugusid.

Seega pole olnud lihtne aru saada, millisena mõistab üks või teine vestluskaaslane minu enda positsiooni usulises plaanis. Tagantjärele olen saanud teadlikumaks ka omaenda eelarvamuslikkusest, kui eeldasin, et oma akadeemilisele taustale viitamine peaks mu (usklikele) vestluskaaslastele tingimata osutama mu sekulaarset maailmavaadet. Valesti mõistmised võivad aga tekitada ebamugavaid olukordi näiteks juhul, kui usklik inimene on mulle rääkinud isiklikest üleelamistest oma vaimses elus ning oodanud seejärel, et jagaksin sarnaseid kogemusi, sattudes segadusse ja olles ehk isegi mõnevõrra häiritud, kui mõistab, et mina ei peagi end usklikuks.

\section{Mitteusklikuna usklikke uurides}

Edasi on minu eesmärk arutleda lähemalt nende väljakutsete üle, millega olen (evangeelsete) usklike seas välitöid tehes kokku puutunud. Osa problemaatikast,

[6] Koguduse kujunemise ja iseloomu kohta lähemalt vt Koosa 2013. 
mida järgnevalt esile toon, pole aktuaalne üksnes religioossete kogukondadega tegeledes, vaid võib kerkida esile mistahes teemal etnoloogilist uurimust tehes. Ometi on religioosse sfääriga tegelemisel oma spetsiifika, mis toob kaasa teatud küsimused mitte ainult uuritavatelt, aga ka kolleegidelt. Mitmed evangeelsete kristlaste uurijad on kirjeldanud, kuidas nende uurimisaines on akadeemiliste kolleegide seas andnud alust teha oletusi uurija enda usulise identiteedi ja eelistuste kohta (vt nt Harding 1991: 375; Cannell 2006: 4). Aastate jooksul olen ka ise korduvalt sarnaste eelarvamustega kokku puutunud.

Iseloomustan järgnevalt taolisi hoiakuid kolme põgusa näitega reaktsioonidest, millega olen oma uurimismaterjali kolleegidele tutvustades vastamisi sattunud. Pärast seda, kui olin oma uurimistööd seminaris tutvustanud, uuris mu kaasdoktorant mõnevõrra üleoleval toonil, ${ }^{7}$ kas ka mind on juba usku pööratud. Ühel teisel korral üllatas mind ettekande järel kolleegi küsimus, millest kõlas läbi tema eeldus, et minu huvi evangeelsete kristlaste uurimise vastu tuleneb isiklikust kuulumisest samasse kogukonda. Üks teine kolleeg, kes ise on teinud välitöid mittekristlike usklike seas, tundis mu uurimisvaldkonnast kuuldes huvi, kas see ei tekita minus isiklikku vastumeelsust või eetilist konflikti põhjusel, et „evangeelsetele kristlastele on iseloomulik omaenda universaalse tõe pealesurumine teistele“. Evangeelsete kristlaste uurimist peetakse seega sageli mingil moel vastuolulisemaks ja nõudlikumaks kui mõnd teist uurimisteemat. Selgitamaks oma tausta ja lähtepositsiooni pean ütlema, et ma ei ole kunagi olnud ühegi koguduse liige ega järginud muul moel mõnd religioosset õpetust või traditsiooni ning määratleksin end mittereligioosse või agnostilise maailmavaatega inimesena. Ehkki erinevad religioossed traditsioonid ja vaimsed praktikad on minu jaoks huvipakkuvad, ei ole mu huvi lähtunud isiklikest otsingutest, vaid tõukunud antropoloogilisest huvist ümbritseva maailma mõtestamise erinevate viiside vastu.

Välitööd usklike seas tõid ootuspäraselt kaasa vajaduse selgitada uuritavatele omaenda suhet usuga. Esmalt olid minu välitööde fookuses õigeusklikud inimesed. Võrreldes evangeelsete kristlastega ei tegele õigeusklikud enamasti aktiivse misjonitööga. Veelgi enam, õigeusklike jaoks seostub usk etnilisusega. Ehkki nendest asjaoludest tulenevalt ei kogenud ma õigeusklikega suheldes erilisi katseid mind usku pöörata, tunti sellegipoolest huvi minu enda usulise kuuluvuse vastu. Selgitasin sellistel puhkudel, et ma ei ole usklik (неверующая ${ }^{8}$ ), kuna taoline vastus tundus olevat kõige ausam. Pärast seda, kui kohtusin eaka naisega, kes sellist vastust väga pahaks pani ja teatas, et inimene ei tohi mingil juhul jumalat avalikult eitada, sest see on suurem patt kui valetada uskumise kohta, muutsin mõnevõrra oma lähenemist. See kogemus tegi mind teadlikumaks asjaolust, et minu püüd olla oma arusaamade järgi võimalikult aus ${ }^{9}$ võib sügavalt solvata vestluskaaslase usu-

[7] On tõenäoline, et patroneeriva hoiaku võtmist soosisid asjaolud, et kõnealune doktorant oli mees ja minust oluliselt vanem.

[8] Välitööd toimusid vene keeles. Külakomid on kakskeelsed - kodune keel on enamasti komi keel, kuid näiteks kooliharidus ja asjaajamine on venekeelsed. Doni kristlaste koguduses on peamiseks suhtluskeeleks vene keel. See tuleneb asjaolust, et pastor on venelane ning ka mõned koguduse liikmed (vene ja ukraina taustaga) ei oska komi keelt.

[9] Väärib märkimist, et seejuures ei kogenud ma samalaadseid kõhklusi, sobitades oma käitumist kohalike ootustega näiteks soorollide käsitlemisel. Kuigi see võis mõnes situatsioonis 
lisi tundeid. Et sellele probleemile võib vaevalt leiduda üks ja lihtne lahendus, on minu vastuseks olnud lihtsalt suurem ebamäärasus, kirjeldades oma suhet usuga, ning vahel olen ehk ilmutanud ka suuremat nõusolekut, kui tegelikult tunnen, võimaluse suhtes, et suhtlemine usklikega võib mindki usklikuks saamisele suunata. Näiteks vastates küsimusele, kas olen usklik, nendin, et kirikus ma ei käi või (evangeelses kontekstis) nõustun arvamusega, et jumal pole veel mu südant puudutanud. Kuid isegi juhul, kui selgelt väljendada oma mitteusklikkust, ei tähenda see, et uuritavad taolise seisukoha üksüheselt omaks võtaksid. Nagu ka teised uurijad on osutanud, mõistetakse võõra aktiivset huvi inimeste usukogemuse vastu, teenistustel käimist ja muud taolist uurija sisemiste jumalaotsingute väljendusena hoolimata sellest, kuidas ta ise oma eesmärke selgitab (vt Harding 2000: 40; Coleman 2008: 43; Meintel, Mossière 2012: 145; vt ka Crane 2012: 14-15 näide välitöödest budistlikus kogukonnas).

Ka suhteliselt pikk suhe kogukonnaga on kaasa aidanud meie kui võ̃oraste staatuse hägustumisele. Mõned koguduse naistest, kellega mul on aastate jooksul sõbralik suhe tekkinud, tervitavad mind embusega - tegemist on kehalise praktikaga, mis enamasti on kasutusel usklike kogukonna sees. Teenistusruumi seinal oleval infotahvlil, millel ripuvad väljavõtted pühakirjast ja jutlustest, fotod koguduse ettevõtmistest ja muud taolist, on grupifoto, kus ka meie peal oleme. Pastor Andrei on naljatleval toonil osutanud meile kui „peaaegu omadele“ (почти наши). Selle määratluse mitmemõttelisust ilmestas juhtum, mil pastor kasutas nimetatud väljendit, ulatades meile oma Kulömdini tuttavatele jagamiseks peotäie kaarte, mis tähistasid ja selgitasid issandamuutmise püha.

Õigupoolest pole me etnoloogidena ainsad kogudusega seotud inimesed, kelle staatus on kuidagi vahepealne või ebamäärane. Et kogudus on oma lähenemiselt väga avatud, pole sugugi kõik iganädalastel teenistustel osalejatest üheselt evangeelse maailmavaate pooldajad. Nii näiteks külastavad mõned naised aeg-ajalt ka õigeusu kirikut ning mõned tunnistavad, et jumal pole veel nende südant puudutanud, kuid nad käivad kirikus oma lähedaste toetamiseks. Arvestades, et kirikus käijate taust ja põhjused teenistustel osaleda on üsna mitmekesised, võib oletada, et see on aidanud ka etnoloogilisest huvist ajendatud külalistel sujuvamalt sobituda kirikuliste seltskonda. Sellele vaatamata on selge, et uurimistööst ajendatud eesmärgid ja vernakulaarsed põhjused olla kogudusega seotud on põhimõtteliselt erinevad ning kristliku maailmavaate ja usu olemuslikult erinev käsitlemine on teatud pingete allikas meie suhetes. Etnoloogina käsitlen ma (evangeelset) kristlust ühe võimaliku maailma mõistmise viisi ja selles olemise raamistikuna, usklike jaoks on niisugune vaade põhimõtteliselt ekslik. Pastor Andrei on sel teemal pikalt arutlenud, järgneva tsitaadi abil toon esile mõned tema põhiseisukohad.

See on praegu suurim eksiarvamus, kui räägitakse, et humanism [on kõige tähtsam]. [...] Kui me asetame inimese ilmaruumi keskpaika, kuhu jääb siis Looja, kes selle inimese lõi? [...] On muidugi kahju, et Euroopa peab ennast postkristlikuks või postmodernistlikuks või midagi.

olla mõnevõrra frustreeriv isiklikus plaanis, ei tajunud ma seda eetilise probleemina tähenduses, justkui oleksin ma nii kuidagi ebasiiras. Pigem on kohalike normide ja ootuste järgi käitumine osa etnoloogilisest osalusvaatlusest ning seega osutavad kaasnevad väljakutsed religioosse sfääriga tegelemisel taaskord selle valdkonna eripärale. 
[...] Humanism annab väga relativistliku kontseptsiooni, sellise suhtumise moraalsetesse väärtustesse. Noh, sina arvad, et see on halb, aga mina arvan, et see on hea! [...] Tuleb välja, et kui ei ole absoluutseid tõdesid, kellel siis õigus on? [...] Kõik väärtused kukuvad kokku, kui ei ole absoluutseid tõdesid. (VM 2011)

Ehkki Andrei ei ütle otse, et meie vaatenurk on ekslik, on tema üldine Euroopa ja relativismi kriitika kaudselt suunatud ka meie esindatavale teaduslikule perspektiivile. Kultuurilise relativismi põhimõte, mis on etnoloogi töös erinevate kogukondade mõistmisel määrava tähtsusega, muutub evangeelses käsituses moraalseks relativismiks.

Teatud segadus meie eesmärkide mõistmisel on seotud rahvapärase arusaamaga etnoloogilise uurimistöö ainesest, milleks levinud arvamuse kohaselt on peaasjalikult vana, traditsiooniline talurahvakultuur. Näiteks oli üks kogudusse kuuluv naine ülikoolikursuse raames puutunud kokku kohaliku folkloori kogumisega. Temaga intervjuud kokku leppides selgitasime oma huvi nii tema isiklike kogemuste kui kohaliku usuelu vastu laiemalt. Teda külastades selgus, et ta oli valmistanud konspekti, mis puudutas paganlike komide võitlust kristlusega 14. sajandil, komi mütoloogiat ja uskumusi ning naaberrajoonis elavate vanausuliste kombeid, mis tundusid kõneleja jaoks kummalistena. Ehkki ta oli valmis rääkima ka omaenda pöördumisloost ja elust evangeelse kristlasena, ei pidanud ta sedalaadi teavet „teadustöö" seisukohast huvipakkuvaks.

Toodud näide ilmestab ka seda, et usklikud ei pea evangeelset kristlust etnoloogilise uurimise võimalikuks objektiks (vrd Vallikivi 2011: 87), mis omakorda osutab mu usklike välitööpartnerite ja minu enda maailmavaate põhimõttelisele erinevusele. Ehkki taoliste erinevuste ületamise võimalikkus on küsitav, on minu roll võ̃orana siiski mõneti tinglik koguduse avatud ja inklusiivse suunitluse tõttu. Usklike seas ei ole selget ja üheselt jagatud suhtumist minusse või minu rolli uurijana ning see tingib võimaluse ja vajaduse mõtiskleda erinevate lähenemiste üle, mida usklikud on meie suhtes kasutanud.

\section{Usklike tõlgendused ja strateegiad etnoloogidega suheldes}

Toon esile kolm erilaadilist lähenemist, mida Doni koguduse kristlased meiega suheldes on kasutanud. Iga lähenemisviis on ilmestatud tsitaatidega informantidelt, kes on vastavat suhtumist või strateegiat kõige selgemalt väljendanud. Minu eesmärk neid lähenemisi käsitledes on analüüsida usklike ja uurijate vahelise suhtluse ambivalentsust. Selle dialoogilise suhtluse analüüsimine võimaldab mõtestada viise, kuidas luuakse teatud ühisosa religioossete ja etnoloogiliste eesmärkide vahel, mis jäävad samas alati mingil määral teineteist välistavaks.

Juba esimesel kohtumisel evangeelse kogukonna esindajatega kerkis esile küsimus tõelise ja olulise teadmise allikatest. Intervjueerisime ameeriklasest misjonäri ning meie vestluse lõpupoole muutus ta murelikuks meie huvi ajendite osas, osutades mitmele ebameeldivale kogemusele ajakirjanikega, kes olid temaga rääkinud ja kirjutanud hiljem asju, mis Williami sõnul polnud tõsi. Kui püüdsime selgitada 
oma eesmärke etnoloogidena, kinnitades talle, et meie huvi on akadeemilist laadi, ja selgitades, mida see tähendab, reageeris ta tungival toonil, paludes, et peame rääkima ainult tõtt, ning väljendas lühidalt ka oma arusaama sellest, mis on tõde ja kus see peitub, sedastades järgmist.

Ilmselt oleksin pidanud teiega rääkima enne, kui alustasime ... Ma palun teilt mõlemalt ainult üht asja [...], et te ei valetaks. Et te räägiksite ainult tõtt. Et te ei lisaks ega võtaks ära. Paljud teleajakirjanikud on siia tulnud ja mida me järgmiseks näeme, me loeme või kuuleme sellest televiisorist - ja see on vale. Nad on lisanud asju, mis pole tõsi. Ja ma lihtsalt palun teid, palun rääkige ainult tõtt. [...] Kui te olete tõepoolest huvitatud teadusliku uurimistöö tegemisest, peaksite piiblit uurima. Ja vaatama, kas see osutub tõeks. Kuidas te saate maha teha raamatut, kui te pole seda kunagi lugenud? (Paus) Miks ei võiks te seda lugeda, teada saada, näha, kas see on tõde või mitte. [...] Sest see on tõde. (VM 2008)

Ühelt poolt kinnitab William oma sõnavõtuga teatud stereotüüpset kuvandit (evangeelsetest) usklikest. Teisalt esindab see vaade evangeelsetele kristlastele tõepoolest üldiselt iseloomulikku seisukohta, mille järgi on piibel ülima ja lõpliku tõe allikas. Samas on koguduse liikmetega vesteldes ilmnenud, et kuigi nad rõhutavad pühakirja uurimise olulisust, ei loe paljud neist piiblit just sageli. Mõned inimesed on tunnistanud, et nad eelistavad näiteks religioosseid raadioprogramme kuulata põhjusel, et seda on kerge ühildada igapäevatoimetustega, aga väljendanud ka tunnet, et iseseisvalt piiblit lugeda on nende jaoks liiga keeruline.

Õigupoolest osutab William oma väljaütlemises kahele erinevale tõe ",tasandile“. Rääkides ajakirjanikest, viitab ta väidetele, nagu oleks tema näol tegu Ameerika spiooniga või et evangeelsed misjonärid meelitavad inimesi oma grupiga liituma altkäemaksu abil. Seega on tegu väidetega, mis liigituvad valeks ilmalikust perspektiivist lähtuvalt. Kui William aga rõhutab, et peaksime tõde otsima piiblist, lülitub ta oma lähenemises ümber religioossele vaatenurgale, mille järgi ainus tähenduslik tõde on transtsendentaalne ning ligipääsetav ja mõistetav vaid usklikule.

Et evangeelsed kristlased tunnevad, et neile on pöördumise käigus tõde ilmutatud, ning tajuvad vajadust jagada seda tõde nendega, kes on endiselt teadmatuses (sh mitteusklikud etnoloogid), on küsimus tõe olemusest meie välitööde käigus korduvalt esile tulnud. Etnoloogina pole mina aga põhimõtteliselt valmis aktsepteerima ideed ühest ja ainsast tõest, nähes pigem ambivalentsust ja suhtelisust mistahes väites või kogemuses, millega ma kokku puutun. Sellest tulenevalt väljendavad usklikud sageli teatud üleolekutunnet mitteusklike suhtes, kes nende arusaama järgi kobavad pimeduses võimetuna mõistma ja vastu võtma vabastavat elumuutvat tõde. Ja hoolimata sellest, kui empaatiliselt taolist arvamust uurijana analüüsida, subjektiivselt võib seesuguse patroneeriva suhtumisega hakkama saamine pakkuda omajagu väljakutset (vrd Clough 2006: 265-266).

On huvitav märkida, et William demonstreerib omaenda eelarvamuslikkust ilmalike uurijate suhtes, lõpetades oma palve üleskutsega piiblit „mitte maha teha“. Õigupoolest polnud kumbki meist mingit sellesuunalist kalduvust ilmutanudki. Arvestades isikliku pöördumise olulisust evangeelses ideoloogias, on mõneti üllatavgi, kui keeruline on olnud selgitada, et just isiklikud kogemused pakuvad meile enim huvi. Usklikud tähtsustavad isiklikku kogemust eelkõige tunnistamise kontekstis, n-ö tõendi või näidismaterjalina selle kohta, kuidas jumal on nende 
elu muutnud. Kui palju on inimesel huvi teise inimesega suhelda, sõltub suuresti muidugi konkreetsest isikust. Williami puhul võib väita, et tema huvi meie kui inimeste vastu oli tagasihoidlik, tema jaoks paigutusime lihtsalt „mittepäästetute“ kategooriasse.

Williami üheselt mõistetava ja omaenda maailmanägemise viisi kõrval teistsugustele käsitustele ruumi mitte jätva avalduse järel sekkus vestlusse samuti juures viibinud pastor Andrei, kes valis meiega suhtlemiseks üsna erineva diskursiivse lähenemise. Ta pöördus meie poole märksa leebemal, ehk isegi mõnevõrra lepitaval moel, tuues esile, et piiblit lugeda oleks kasulik kasvõi silmaringi laiendamiseks.

Andrei: Või vähemasti ei teeks see teile kahju üldiste taustateadmiste saamiseks ...

William: Jah.

Andrei: ... kui te piiblit tunnete. Sest et suurem osa maailma tsivilisatsioonist, teate - kultuur, muusika, arhitektuur -, on kuidagi seotud piiblilugude, kristlusega. Ja mida paremini te seda teate, seda rohkem on teil taustainfot. Isegi oma uurimistöös. (VM 2008)

Andrei, kes on hariduselt filoloog, argumenteerib toodud tsitaadis näiliselt üsna ilmalikul moel piibli lugemise kasulikkuse poolt, tuues esile intellektuaalset, oma teadmiste täiendamise aspekti. Samas tuleb meeles pidada, et evangeelsed kristlased väljendavad vahel ka arvamust, et jumalasõnal sel kujul, nagu see piiblis kirjas on, on seesugune sisemine mõjuvõim, et see võib ka religioosse motivatsioonita, ükskõikse või skeptilise lugeja ainult teksti vahendusel usku pöörata.

Ehkki kokkuvõttes sarnaneb Andrei sõnum Williami omaga, võtab pastor oma lähenemises palju suuremal määral arvesse konkreetseid vestluskaaslasi ning lähtub meie sekulaarsest ja akadeemilisest taustast. Hilisemate välitööretkede käigus on pastor Andrei näidanud üles üsna suurt huvi meie töömeetodite ja -põhimõtete vastu. Lisaks kõrgkoolis õppimise kogemusele (mis on olemas ka mõnedel teistel koguduse liikmetel) oskab Andrei peale Williami koguduses ainsana inglise keelt, mis võimaldab tal ka meie valdavalt inglise keeles avaldatud artikleid lugeda. Seega on tal ilmselt parem ettekujutus meie tööst kui teistel koguduse liikmetel.

Andrei suhtumist meisse kui mitteusklikesse teadlastesse ilmestab veelgi paremini väljavõte vestlusest, mis on salvestatud ühe koguduseliikme kodus külas olles.

Andrei: Aga kui te kirjutate artikli, siis te loomulikult midagi korrigeerite, te võtate midagi välja. Kuidas te asetate rõhud? Kas te kirjutate sellest, mida jumal reaalselt meie elus on teinud, Jeesus Kristus?

Art: No ilmselt kirjutame me teadustöös nii, et teie usute niimoodi.

[...]

Andrei: Ma olen teiega nõus ja see on teie töö ja teatud kohtades peate te olema neutraalsed, aga teisest küljest arvan ma, et teie töös ...

Sveta: Tegutseb issand.

Andrei: Tegutseb issand.

Anna: Ma arvan samamoodi.

Andrei: Kuidas tuvastatakse tõde kohtus? [...] See tuvastatakse läbi tunnistajate tunnistuste, astub ette üks tunnistaja, [...]astub ette teine, kolmas ja kohtuasi ehitatakse nende peale üles. Niimoodi tehakse igas kohtus. Kuidas tuvastada tõde, kellel on õigus ja kellel ei ole 
öigus. Isegi mitteusklike kohtus tehakse niimoodi. Ja seetõttu, see, et te kogute siin informatsiooni, sellega kogute te faktiliselt teatud mõttes tunnistajate tunnistusi inimestelt, kes on oma elus midagi läbi elanud. Ja seetõttu faktiliselt see, ma arvan, et see on küllaltki väärtuslik materjal. Ma ei tea, kas seda on võimalik nimetada tõestusbaasiks, sest jumala olemasolu tõestada inimesele, kes seda ei usu, ei ole võimalik. Just selle pärast jumalat usutaksegi. Kui jumala olemasolu oleks võimalik tõestada, siis ei oleks vaja temasse uskuda. Õige? Sest et seda tõestada teaduslikust vaatepunktist ei ole reaalne, sest alati leidub skeptikuid. Aga skeptikud saavad alati olema kuni viimsepäeva kohtuni. Seal enam skeptikuid ei ole. (Naerab) (VM 2012)

Siinkohal pöördub Andrei meie poole, püüdes taaskord kasutada teaduslikku diskursust, tunnustades seeläbi meie enesemääratlust sekulaarsete uurijatena ning väljendades arusaamist ideest, et n-ö teaduslikud väited peavad põhinema empiirilisel ja tõendataval materjalil. Seejärel esitab ta väite, et ehkki me ise (veel) seda ei mõista, on meid selle konkreetse uurimisteema juurde toonud meie sisemised jumalaotsingud ja õigupoolest jumal juba kasutabki meid vahendina, sest me kogume ja levitame tõendusmaterjali tema kohta. Kokkuvõttes argumenteerib Andrei selgelt erapooletu või „,teadusliku“ seisukoha võimalikkuse vastu, mida me uurijatena püüame võtta, osutab taolise positsiooni kahjulikkust vaimses plaanis, lõpetades oma arutluse pisut iroonilisel toonil, kui meid kaudselt skeptikutena adresseerib.

Kolmanda ja teatud mõttes eelnevatest hoopis erineva näitena meie välitööpartnerite lähenemisest uurijatele esitab Irina. Irina sügavam huvi usu vastu ning aktiivsem kirikus käimine sai alguse pärast seda, kui ta pensionile jäi. Varem oli Irinal rohkem kokkupuuteid õigeusu traditsiooni ja kirikuga, nüüd käib ta innukalt evangeelse koguduse teenistustel. Samas külastab ta endiselt aeg-ajalt ka õigeusu kirikut. Olles veendunud usklik ning rääkides usu tähtsusest ka oma perele ja sõpradele, tunnistab ta samas, et erinevad denominatsioonid ja nende õpetuslikud erinevused tekitavad temas omajagu segadust. Asjaolu, et Irina abikaasa ei kiida heaks tema seotust evangeelse kirikuga, põhjustab talle samuti meelehärmi. Pärast seda, kui meid tutvustati Irinale usuelu uurivate teadlastena, on ta meid käsitlenud religioonialaste spetsialistidena mõneti ootamatul moel. Meie vestluste käigus on ta mitmel korral küsinud kinnitust oma arvamusele, et evangeelne kristlus on tõepoolest hea usk. Minu jaoks oli üpris ootamatu Irina arutluskäik, et kui meiesugused noored ja haritud inimesed nende kiriku vastu huvi tunnevad, on see järelikult külastamiseks sobilik. Õigupoolest on ta samamoodi leidnud ka, et küllap see kirik on hea, sest pastor ja tema abikaasa on noored, kenad ja haritud inimesed. Irina käsitluses kannab seotus ülikooliga ja teadusega tegelemine iseeneses teatud väärtust. Seeläbi omandame meiegi autoriteetse positsiooni ja peaksime eeldatavasti olema võimelised andma selgeid hinnanguid ja ütlema, mis on õige.

Ma ei ole otsustanud, et käin ainult seal [evangeelses kirikus], ma tahan käia ka õigeusu kirikus ja seal seista ja siin käia. Aga rohkem pole ma kuskil olnud. Aga teie olete ju igal pool olnud. Aga kuidas nelipühilastel on, kas nad usuvad ainult jumalat, Jeesus Kristust? Ja on, kes usuvad ainult jumalaema. [...] Aga kas te teate veel neid, kus on Jehoova tunnistajad? See [Jehoova] on jumala nimetus, see on piiblis ka kirjas, et me kõik räägiksime seda nime. Ja ma mõtlen, et miks praegu varjatakse seda nime - need usud lähevad mul sassi. [...] Aga ma loen 
hästi palju ainult piiblit, teie teate minust rohkem, aga seal on kirjas, et tullakse minu nime järgi. Aga seal ei ole avaldatud, millise nime. Me teame, et peab Jeesuse poole palvetama, aga ilmselt Jehoova poole ka. Või mida teie arvate? [...] See on selline sasipundar, et mida rohkem loed [erinevate uskude kohta] - ja peas on puder. Tuleb niimoodi välja. (VM 2013)

Irina arusaama järgi pole meie võõra-staatus seega takistuseks tõelisel mõistmisel, vaid pigem omistab ta meile akadeemilise tausta ja eeldatavasti laialdase ning mitmekesise kogemusbaasi põhjal teoloogilistes küsimustes kompetentsi, mille ta endal puudu tunneb olevat. Ühest küljest arvab Irina, et meie huvi ja kohalolu kinnitavad Doni kogukonna respektaablust ja seda, et tegu pole mingi „kahtlase seltskonnaga", nagu leiab tema abikaasa. Teisalt eeldab ta, et teadlastena on meie pädevuses öelda, milline on "õige“ uskumise viis - teadustöö eesmärgina näeb ta seega mingi tõsikindluse, tõe sedastamist.

Olen eelnevas kirjeldanud kolme erinevat evangeelset reaktsiooni teadlase positsiooni võtmisele: katse suruda võorastele tingimusteta peale omaenda tõlgendusviis (William), diskursiivsete kompromisside tegemine, et vähendada kahe osapoole vahelist kontseptuaalset lõhet (Andrei) ja viimaks valmisolek jätta kogu kompetents otsustamises „teadlastele“ (Irina). Suurem osa meie evangeelsetest välitööpartneritest pole väljendanud üheselt ühtki taolist lähenemisviisi. On olnud tavaline, et usklikud teevad üpris tagasihoidlikke katseid meid pöörata, kõneledes jumalaga elamise tähtsusest ning sellest, kuidas nende endi elu on pöördumise tõttu paremuse poole muutunud. Teisalt olen mitmete inimeste puhul tajunud ka soovi saada kinnitust oma valiku õigsusele. Ehkki pastor Andreil endal pole mingeid kõhklusi oma teoloogiliste eelistuste osas, on ta teadlik sellest, et enamik koguduse liikmeid on kogenud sugulaste või teiste külaelanike halvakspanu oma usu pärast, mis öeldakse olevat „vale“. Sellest asjaolust tulenevalt on Andrei puhuti pöördunud ka teiste koguduseliikmete juuresolekul meie poole, et me kinnitaksime tema väidet, et Eestis (ja Euroopas üldse) ei suhtuta evangeelsetesse kristlastesse diskrimineerivalt, nagu Venemaal tavaline on.

See, kui palju konkreetne koguduse liige tegeleb selgelt väljendatud misjoneerimisega, näib teatud määral olevat seotud tema staatuse ja rolliga koguduses (vt ka Blanes 2006: 226). Kui pastor ja mõned teised koguduse kesksemad liikmed on ühel või teisel hetkel meie usu või selle puudumise küsimuse tõsisemalt jutuks võtnud, siis kogudusega nõrgemalt seotud välitööpartnerid pole seda teinud. Mõned neist on väljendanud muret selle pärast, et ehkki nad teavad jumalasõna levitamise tähtsust, puudub neil selleks vajalik enesekindlus ja oskused. Kui isegi oma naabritele või teistele külaelanikele tunnistamine on inimesele väljakutse, on ootuspärane, et ta ei püüa hakata usku pöörama välismaalast, kellel pealegi on tema silmis teatud määral autoriteetne positsioon.

Kuid ka koguduse tuumikliikmete lähenemine sellele küsimusele pole ühemõtteline. Kuigi üldiselt mõistagi räägitakse jumalaga elamise tähtsusest, pole ka grupi kõige aktiivsemad liikmed olnud meie pööramiskatsetega eriliselt peale käivad. Doni kristlased lähtuvad suuresti isikliku eeskuju näitamise põhimõttest. Ärgitatakse küll oma sekulaarset vaatenurka ümber hindama, kuid ei tegeleta agressiivse misjoneerimisega. Pastor Andrei on isegi märkinud, et „ei tea, kas teie usute juma- 
lat või mitte, see on teie isiklik asi, kuid mina usun teda", mis iseloomustab hästi selle koguduse liikmete tagasihoidlikkust eksplitsiitses misjoneerimises.

Pastor Andrei on olnud grupist ainus, kes on mingil määral aktiivselt arutlenud meie teadustöö tegemise ja eesmärkide teemal, samas kui enamik teisi on sellesse üsna ükskõikselt suhtunud. Aga isegi Andrei on väljendanud teatud arusaamatust meie eesmärkide osas, märkides, et „te teate juba kõike ja midagi uut pole rääkida“. Aeg-ajalt on ta sõbralikult aasides pärinud, kas oleme „järgmise uurimuse tarbeks juba piisavalt materjali saanud“. Oleme talle ka oma ilmunud artikleid näha saatnud, kuid suuremat huvi ta nende vastu üles pole näidanud. Oletan, et see tuleneb asjaolust, et meie artiklid tegelevad küsimustega, mis usklike silmis ei ole esmatähtsad. Kuid kuni me ei väida asju, mis on vastuolus meie ühise reaalsusega, ei tunne pastor nähtavasti vajadust meie väljendatud mõtetele ja arutlustele vastu vaielda.

Mõistagi on lisaks eeltoodutele ka muid põhjuseid, mis meie välitööpartnerid meiega suhtlema motiveerivad. Näiteks on Irina näinud meis võõrastena ka tänuväärseid kuulajaid, kellele on võimalik väljendada rahulolematust teiste grupi liikmete käitumisega. Ehkki Irina ei taha oma kaasusklikke arvustada, täheldab ta inimeste käitumises jooni, millega ta rahul pole. Kord enne taoliste näidete toomist kinnitas ta, et „ma räägin seda esimest korda, ma kuulujutte ei armasta, aga teil on ju teaduse jaoks vaja". Seega põhjendas ta kriitiliste märkuste tegemist meie teaduslike eesmärkide jaoks olulise informatsiooni edastamise raamistikus. Teised koguduse liikmed pole küll nii selgelt seostanud kriitliste arvamuste väljendamist meie kui „objektiivsete“ uurijate rolliga. Siiski on tunda, et nii mõnigi kord on väljapoole kogukonda paigutuva uurijaga suhtlemine võimaldanud arutleda asjade üle, mida kogukonna sees ei puudutata.

Lisaks kõigile spetsiifilisematele eesmärkidele, mis inimestel meiega suheldes võivad olla, poleks õiglane mitte mainida lihtsalt inimlikku huvi meie vastu. Samamoodi usun, et uurida teemat, mis endale sugugi huvi ei paku ja milleks tuleb suhelda enda jaoks ebahuvitavate inimestega, oleks keeruline ka etnoloogi jaoks.

\section{Kokkuvõte}

Minu eesmärk selles artiklis on olnud arutleda uurija ja uuritava vaheliste suhete dünaamika üle. Püüdsin seda teha, tuues esmalt välja kõhklusi ja raskusi, mis minu jaoks usklike uurimisega on kaasnenud, ning seejärel kirjeldades oma välitööpartnerite tõlgendusi ja suhtumist minusse kui mitteusklikku uurijasse. Osutan oma analüüsiga meie dialoogi mitmetahulisusele - ehkki teatud kontseptuaalsed erinevused meie vaadetes on ületamatud, on mingites asjades siiski võimalik jõuda vastastikuse mõistmiseni.

Uurimistöö tegemisel ja välitöömaterjali esitamisel hinnatakse teadusliku ideaalina üldiselt empaatilist, kuid siiski erapooletut lähenemist vaatamata sellele, et tunnistatakse raskusi ja piiranguid „objektiivse“ vaate saavutamisel. Samas pole neutraalne või erapooletu lähenemine usuküsimustele vastuvõetav evangeelsete kristlaste jaoks, kelle jaoks piibel on ülima ja lõpliku tõe allikas. Potentsiaalselt konfliktsete arusaamade väli minu ja mu välitööpartnerite vahel puudutabki eelkõige 
tõe mõistet. Lähtudes vajadusest mõista usklike arusaamu ja praktikaid tervikliku tähendusväljana, mille nad moodustavad, olen samas teadlik sellest, et meie tõeni jõudmise kognitiivsed praktikad on fundamentaalselt erinevad (vt Lambek 2012). Usklike jaoks on esmatähtis nende poolt läbi elatud vabastava ja päästva Tõe sõnumi edastamine kuulajale, mina etnoloogina pole valmis tunnistama üht ainuvõimalikku tõde ning mõtestan evangeelsete kristlaste usku akadeemilise diskursuse raamistikus, mis põhineb empiirilisel vaatlusel ja lähtub suhtelisuse põhimõttest.

Nii põhinebki minu ideoloogiline lähenemine üldjoontes millelgi, mida pastor Andrei irooniliselt „humanismiks“ nimetab. Olen teadlik ka sellest, et intellektuaalne traditsioon, mille raames ma oma uurimistööd teen, sisaldab endas kristlusega võrreldes üpris palju vastuolusid ja ümbermõtestamisi (vt Hufford 1995: 71). Kuid samas võimaldab mu enda mitte läbinisti harmooniline erialane vaatenurk näha sidusust usklike maailmavaates ning olla seda analüüsides ja järeldusi tehes mitte üleliia kategooriline. Ma ei saa küll kindlalt väita, et suudan oma kirjutistega esitada evangeelses tähenduses täiesti tõepärase pildi kogudusest - usklike kogetav tegelikkus, mis põhineb transtsendentaalsel tõel, pole minu jaoks tervikuna vaadeldav ega lõpuni mõistetav. Seega jääb mõnevõrra lahtiseks küsimus sellest, mil määral meie tegelikkusetaju kattub ja, sellest lähtuvalt, mil määral ühilduvad meie arusaamad tõest.

Et aga usklikud on olnud valmis minuga suhtlema (omistades mulle isegi oma sõnumi vahendaja rolli hoolimata mu enda kavatsustest), osutab see asjaolule, et nad ei pea mind põhimõtteliselt võimetuks andma edasi teatava tõeväärtusega pilti nendest. Samas on evangeelsete kristlaste eripärane sotsiokultuuriline kontekst Komi külas ning nende teoloogilised arusaamad samuti mõjutanud minu ligipääsu sellele kogukonnale ja kujundanud ka nende suhtumist minusse. On põhjust oleta$\mathrm{da}$, et ainuüksi minu empaatiline suhtumine üldiselt mõnevõrra vaenulikult meelestatud keskkonnas on lihtsustanud mu ligipääsu kogudusele ning seetõttu pean oma järeldusi ja tõlgendusi esitama eriti hoolikalt, vältimaks mitmeti mõistmisi eetilises plaanis.

Välitööd evangeelsete kristlaste seas kujutavad endast dialoogi, mis kannab osapoolte jaoks erinevaid tähendusi ja milles kummalgi poolel on oma eesmärgid. Meie dialoogi piirab see, et ma ei ole pöördunud ja mul puudub selleks ka teadlik soov. Kuid samas ei esita ma otseselt ka väljakutset evangeelsele maailmavaatele. Meie suhtlus pole seega usklike silmis kõige olulisemas plaanis funktsionaalne. Sotsiaalsed suhted ja muu taoline, mis mulle etnoloogina huvi pakuvad, on ka usklike jaoks teatud määral olulised, kuid mitte tingimata kõige tähtsamad nende diskursiivse enesemääratluse seisukohalt. Et meie maailma mõistmise ja tunnetamise viisid erinevad, on meie vahel paratamatult teatud kognitiivne distants. Dialoog on siiski võimalik, sest partneritena on meil piisavalt vastastikust lugupidamist ning et akadeemiline tõetaju ja tõeni jõudmise vahendid on ühildamatud religioossete tõdede ja nendeni jõudmise vormidega, ei püüa teaduslikud väited religioosseid tingimata asendada ega neile vastanduda (Lambek 2012). Tunnustades omavahelisi põhimõttelisi tunnetuslikke erinevusi, suudame me olla teineteisele mõistetavad ja vastastikku kasulikud partnerid. 
Käesolevat artiklit võib käsitleda metodoloogilise visandina välitöödeks evangeelsete protestantide seas. Esitatud mõtted ja arutelu kehtivad siiski vaid konkreetse grupi, sellega seotud isikute koosluse ja sotsiaalse keskkonna kontekstis. Mistahes teise evangeelse kristlaste kogukonna puhul peab lähtuma konkreetsele grupile omasest usu väljendamise intensiivsusest ja tolerantsist teistsuguste vaadete suhtes ning oma metodoloogilist lähenemist vastavalt sellele kohandama.

\section{Allikad}

VM = 2008-2013 Komi Vabariigi Kulömdini rajooni külades kogutud välitöömaterjalid (autori valduses).

\section{Kirjandus}

Blanes, Ruy Llera. 2006. The atheist anthropologist: believers and non-believers in anthropological fieldwork. - Social Anthropology 14 (2): 223-234.

Cannell, Fenella. 2006. Introduction. The anthropology of Christianity. - The Anthropology of Christianity. Ed. by Fenella Cannell. Durham, London: Duke University Press, 1-50.

Clough, Paul. 2006. Social thought and commentary. "Knowledge in passing": reflexive anthropology and religious awareness. - Anthropological Quarterly 79 (2): 261-283.

Coleman, Simon. 2008. The abominations of anthropology: Christianity, ethnographic taboos and the meanings of 'science'. - On the Margins of Religion. Ed. by Frances Pine, João de Pina-Cabral. New York, Oxford: Berghahn Books, 39-58.

Crane, Hilary. 2012. Flirting with conversion: negotiating researcher non-belief with missionaries. - Missionary Impositions. Conversion, Resistance, and other Challenges to Objectivity in Religious Ethnography. Ed. by Hilary K. Crane, Deana Weibel. Lanham: Lexington Books, 11-23.

Gardiner, Mark Q.; Steven Engler. 2012. Semantic holism and the insider-outsider problem. - Religious Studies 48 (2): 239-255.

Harding, Susan. 1991. Representing fundamentalism: the problem of the repugnant cultural other. - Social Research 58 (2): 373-393.

Harding, Susan. 2000. The Book of Jerry Falwell: Fundamentalist Language and Politics. Princeton: Princeton University Press.

Hufford, David J. 1995. The scholarly voice and the personal voice: reflexivity in belief studies. - Western Folklore 54 (1): 57-76.

Jensen, Jeppe Sinding. 2011. Revisiting the insider-outsider debate: dismantling a pseudoproblem in the study of religion. - Method \& Theory in the Study of Religion 23 (1): 29-47.

Koosa, Piret. 2010. Õigeusk kaasaegses komi külas. Tartu: Tartu Ülikooli Kirjastus.

Koosa, Piret. 2013. Sowing the seeds of faith: A case study of an American missionary in the Russian North - Journal of Ethnology and Folkloristics 7 (1): 31-48.

Koosa, Piret. 2017. Negotiating Faith and Identity in a Komi village: Protestant Christians in a ProOrthodox Sociocultural Environment. Dissertationes Ethnologiae Universitatis Tartuensis 7. Tartu: University of Tartu Press.

Koosa, Piret; Art Leete. 2011. Revolt of grannies: Komi folk Orthodox movement Bursylysyas. - Journal of Ethnology and Folkloristics 5 (1): 45-61. 
Lambek, Michael. 2012. Facing religion, from anthropology. - Anthropology of this Century 4, May. http://aotcpress.com/articles/facing-religion-anthropology/ (viimati külastatud 15.9.2017).

McCutcheon, Russell T. 1999. General introduction. - The Insider/Outsider Problem in the Study of Religion: A Reader. Ed. by Russell T. McCutcheon. London, New York: Continuum, 2-11.

Meintel, Dierdre; Géraldine Mossière. 2012. Going through the back door. Studying ethnicity via religion. - Where is the Field? The Experience of Migration Viewed through the Prism of Ethnographic Fieldwork. Studia Fennica. Ethnologica 14. Ed. by Hanna Snellman, Laura Hirvi. Helsinki: Finnish Literature Society, 128-149.

Vallikivi, Laur. 2011. Words and Silence: Nenets Reindeer Herders' Conversion to Evangelical Christianity. Doctoral dissertation. University of Cambridge, Scott Polar Research Institute.

Wanner, Catherine. 2011. Afterword: Multiple moralities, multiple secularisms. - Multiple Moralities and Religions in Post-Soviet Russia. Ed. by Jarrett Zigon. Oxford: Berghahn, 214-225.

Piret Koosa on Eesti Rahva Muuseumi teadur. Oma uurimistöös on ta keskendunud postsotsialistlikule usuelule Põhja-Venemaal. 2017. aastal kaitses ta edukalt doktoriväitekirja „Negotiating Faith and Identity in a Komi Village: Protestant Christians in a Pro-Orthodox Sociocultural Environment” („Usk ja identiteet komi külas: protestandid õigeusklikus sotsiokultuurilises keskkonnas“). 


\section{Summary: Ethnological fieldwork in a religious community: the case of Komi Christians}

\section{Piret Koosa}

The article is based on fieldwork conducted in the Kulymdin district of the Komi Republic in the years 2008-2015. In the article, I reflexively discuss my own position as a non-religious researcher conducting fieldwork among evangelical Christians. The salience of the issues I deal with is not limited to work with religious communities, and probably also comes up in conducting various ethnological research. Yet dealing with the religious sphere has its own special characteristics that see the research confronted with certain questions not only from the subjects, but also from colleagues.

On one hand, the article deals with my thoughts, experiences and feelings in studying religious people as a non-believer. I also look at the reactions of the believers toward myself, and analyse how my position as a researcher has affected our interactions. I bring out various ideological points of departure and contextual circumstances that form the backdrop to our communication and have shaped our dialogue. In addition to our various personal experiences and attitudes, the specific sociocultural environment in which our interaction took place has also had a role. I also reflect on various motivations that may have led people to take part in interaction and I deal with the difficulties involved in elucidating my own objectives.

As an ethnologist, I have a specific goal when I conduct fieldwork, and later, in presenting the gathered material as a scholar, I take a certain authoritative position. At the same time, the subjects in our mutual interaction also have their own reasons and objectives. The subjects' opinion of what the result of our interaction should be may be significantly different from mine. The ideal in research and presentation of material gathered in fieldwork is generally considered to be an empathetic yet impartial approach, in spite of the fact that difficulties and limitations are acknowledged in achieving an 'objective' view. At the same time, a neutral or impartial approach to religious matters is not acceptable for evangelical Christians. As a researcher, I see Christianity as one possible mode of existence in the world and framework for making sense of that world, yet believers would see such a standpoint as mistaken. The fact that I have not converted and have no conscious desire to do so puts limits on our dialogue. Our interactions are thus not functional for believers in what for them is the most important aspect. Yet I have not voiced scepticism in the evangelical world view, either. Although the believers have doubt in my ability as a non-believer to genuinely understand their experiences, there are a number of reasons that they might see a point in communicating with me. Analysing the motivation and strategies of the believers in the communication between us, I identify three angles of approach: the attempt to force their own means of interpretation on outsiders, the making of discursive compromises to close the conceptual gap between the two parties, and the readiness to leave the entire decision-making competence up to 'scholars'. My goal in bringing out these perspectives is to analyse the 
ambivalence in researcher-believer interaction. Enquiry into the polysemantic and multidimensional aspect of our interaction helps us to better see and make sense of ways in which the search for and efforts to establish a certain common ground take place between ethnological fieldwork and religious objectives - which are always to some extent irreconcilable. As our ways of understanding and intuiting the world vary, there will inevitably be a certain cognitive distance between us. By acknowledging the fundamental cognitive differences between us, we can still be understanding of each other and be mutually beneficial partners. 


\section{Резюме: Полевые этнологические исследования в религиозном контексте (на примере христиан Коми)}

\section{Пирет Кооса}

Статья базируется на полевых исследованиях, проведенных автором в 20082015 гг. в Усть-Куломском районе Республики Коми. В статье рассуждаю о своей позиции неверующего исследователя во время полевых работ среди евангельских христиан. Актуальность проблемы авторефлексии не ограничивается работой в редигиозных общинах и, вероятно, может возникнуть при проведении раздичных этнологических исследований. Однако работа в религиозных кругах имеет свою специфику, влекущую к определенным вопросам не только со стороны исследуемых, но и колдег. С одной стороны, в статье издагаю свои мысли, опыт и чувства, возникающие у неверующего при исследовании религиозных людей. С другой, рассматриваю реакции верующих на меня и анализирую, как моя позиция исследователя влияет на наше общение. В статье обращаю внимание на разные идеологические положения и контекстуальные обстоятельства, ставшие фоном взаимоотношений и сформировавшие наш диалог. Помимо личного опыта и установок обеих сторон, свою роль имела особая социокультурная среда, в которой происходило наше общение. Я также рассуждаю о раздичных мотивах, побудивших людей участвовать в этом общении, и рассматриваю трудности, возникавшие при разъяснении своих целей. У меня как этнолога во время полевых работ имеется специфическая цель, и впоследствии, представляя собранный материал в качестве исследователя, я обладаю определенной авторитетной позицией. В то же время, при взаимном общении исследуемые тоже имеют свои цели и причины. Мнение исследуемых о том, каким должен быть результат нашего общения, иногда может значительно отличаться от моих взглядов. При проведении исследований и представлении экспедиционного материала в качестве научного идеала, как правило, ценится эмпатический, но все же беспристрастный подход, несмотря на то, что признаются трудности и ограничения при достижении «объективного» взгляда. В то же время, нейтральный или беспристрастный подход к вопросам веры неприемлем для евангельских христиан. Как исследователь, я рассматриваю христианство как один из возможных способов существования в мире и основа для понимания мира, в то же время для верующих подобная позиция принципиально неверна. То обстоятельство, что я не являюсь обращенной в веру и у меня отсутствует для этого осознанное желание, ограничивает наш диалог. С точки зрения верующих, наши взаимоотношения не являются функционально важными. В то же время, я не ставдю под сомнение евангельское мировоззрение. Хотя верующие и сомневаются в моей (как человека неверующего) способности действительно понять их опыт, все же находится ряд причин, которые дают им смысл для общения со мной. Анализируя мотивы и стратегии верующих к взаимной коммуникации, подчеркиваю три подхода: 1) попытка навязать чужим безоговорочно собственные истолкования; 2) поиск 
дискурсивного компромисса для уменьшения концептуального раскола между двумя сторонами; 3) готовность оставить право решения полностью компетенции «ученых». Рассматривая эти перспективы, ставлю себе целью проанализировать амбивалентность взаимоотношений исследователей и верующих. Исследование многозначности и многомерности наших взаимоотношений позводяет увидеть и понять, как происходит поиск общего между не всегда совпадающими целями этнологических работ и самих верующих. Поскольку наши способы понимания и ощущения мира раздичны, то между нами неизбежно существует определенная когнитивная дистанция. Признавая принципиальные раздичия нашего мировосприятия, мы можем, однако, быть взаимно понятными и взаимно полезными партнерами. 